\title{
The Role of Credence Attributes in Consumer Choices of Sustainable Fish Products: A Review
}

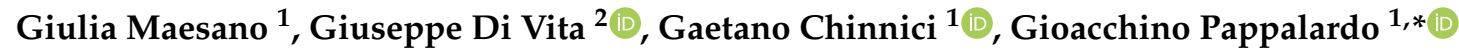 \\ and Mario $\mathrm{D}^{\prime}$ Amico ${ }^{1}$ D \\ 1 Department of Agriculture, Food and Environment (Di3A), University of Catania, Via S. Sofia 98-100, \\ 95123 Catania, Italy; gmaesano@unict.it (G.M.); chinnici@unict.it (G.C.); mario.damico@unict.it (M.D.) \\ 2 Department of Agricultural, Forest and Food Science (Disafa), University of Turin, Largo Braccini, 2, \\ Grugliasco, 10095 Torino, Italy; giuseppe.divita@unito.it \\ * Correspondence: gioacchino.pappalardo@unict.it
}

Received: 30 September 2020; Accepted: 27 November 2020; Published: 30 November 2020

\begin{abstract}
This review aims to assess consumer choices of sustainable fish products, considering a number of attributes that have been considered in the academic literature on this topic. In order to examine the effectiveness of sustainable labels, the research question was focused on the relation between sustainable fish labels and consumers' willingness to pay (WTP). The findings showed how, overall, consumers have positive perceptions regarding sustainable fish products and show a willingness to pay a premium price for the attribute of sustainability. According to the results, the country of origin attribute was found to be the most important attribute in relation to consumer choice. The results indicated a high WTP for local fish products, relative to imported alternatives. Consumers prefer wild-caught fish for its perceived quality, better safety and health aspects, and taste perception than the farm-raised option. As for animal welfare, the results show that consumers are willing to pay a moderate premium price for products that have an improved fish welfare or those that avoid by-catch, such as products with eco-labels like "turtle safe". With regard to organic labels, the studies identified a positive organic price premium for fish products. However, organic labels do not play a major role in consumer choice, when compared with other attributes.
\end{abstract}

Keywords: sustainable fish; review; consumer choices; WTP; credence attributes

\section{Introduction}

Given the current increasing demand for fish products and the consequent depletion of fish stocks and marine natural resources, public concern about sustainable fish production and fishery management has risen. As a result of the growing worldwide population, higher living standards, and widespread recognition of the health benefits of fish consumption, the demand for fish products has been growing worldwide, playing an important role in feeding the world's population. This trend has generated a negative impact on natural resources due to overfishing, which is becoming unsustainable for several fish species and the marine environment [1-7].

With the decline of wild fish stocks, the aquaculture sector has begun to play an increasingly important role in meeting the growing worldwide demand for fish products. Aquaculture can generate a negative impact on environmental resources due to the factors relating to intensive fish farming practices, such as the escape of genetically modified farmed fish, contamination of wild fish stocks, and release of effluents, disrupting the natural performance of marine ecosystems $[1,3,8,9]$.

The growing consumption of fish products and current pressure on natural resources have generated an increasing interest in sustainable fish, adding weight to the call for a shared understanding of sustaining the natural capacity of marine ecosystems to provide food products. The demand for 
sustainable fish has also gained increasing importance in the framework of political discourse on sustainable food systems. The institutional attention regarding sustainable fisheries is also related to the growing consumer interest in the dimensions of sustainability in food products [10-12].

In the modern fish sector, consumers are concerned with all dimensions of sustainability, indicating a sustainability-centric consumer vision. In this regard, it is important for fish producers to meet consumer demand for credence characteristics related to the broad concept of sustainability $[12,13]$.

Consumers are interested in credence attributes, which have several intangible features, such as the sustainable management of natural resources and environmental protection, support for small-scale enterprises, maintenance of local communities, shorter transportation distances of products to local markets, attention to animal welfare, avoidance of incidentally by-caught non-targeted species, and sustainable fishing methods. Thus, the use of labels indicating credence cues has become an important search attribute for consumers and an important instrument in the promotion of sustainable fish products. Food labels related to credence attributes enhance consumer awareness and support consumer choices in line with their attitudes and preferences. However, although consumer attitudes toward sustainability are generally positive, behavioral patterns are not always consistent with consumer choices $[4,6,13,14]$.

Despite the fact that a growing number of studies in the literature on this topic have been carried out in recent decades, the knowledge on the above-mentioned topic in the academic literature is still heterogeneous. Therefore, it is challenging to identify patterns in consumer choices, without analyzing the results of the studies in the literature on this topic [12].

The aim of the paper is to generate a set of findings regarding consumer willingness to pay a premium price for sustainability-labelled fish products in order to provide a brief summary of the current literature on this topic.

In this paper, we conduct a literature review with the objective of obtaining a meaningful description of the findings presented in the academic literature from the period 2000-2020 and a summary of the research concerning the effect of sustainability attributes on consumer choices of fish products. The review was based on a collection of studies on consumer choice regarding a variety of fish and seafood products, from different countries and years.

The paper is organized as follows. In second section, the method and an overview of the selected studies are described. In the third section, the main results of the literature review are summarized. In the fourth section, the results are presented. In the fifth section, concluding remarks are provided.

\section{Materials and Methods}

\subsection{Literature Searching Criteria}

The narrative literature review was carried out in order to select the studies from the academic literature and to summarize the results concerning consumer choices of sustainable fish products.

The selection criteria were identified through a systematic, replicable, and transparent procedure in order to identify specific case studies that examined the WTP for sustainable fish. The review was carried out following the Preferred Reporting Items for Systematic Review and Meta-Analysis (PRISMA) [15-17]. A flow chart is provided in Figure 1.

The Google Scholar database has been used in order to include the relevant literature concerning consumer behavior in relation to sustainable fish products.

The search was carried out in June and July 2020, and it included studies that were conducted after 2000, which was considered to be a suitable range for including the recent trends on the topic under investigation and to avoid outdated articles.

Because of the availability and readability limits of some papers, it was difficult to include all studies from the academic literature in this field. 


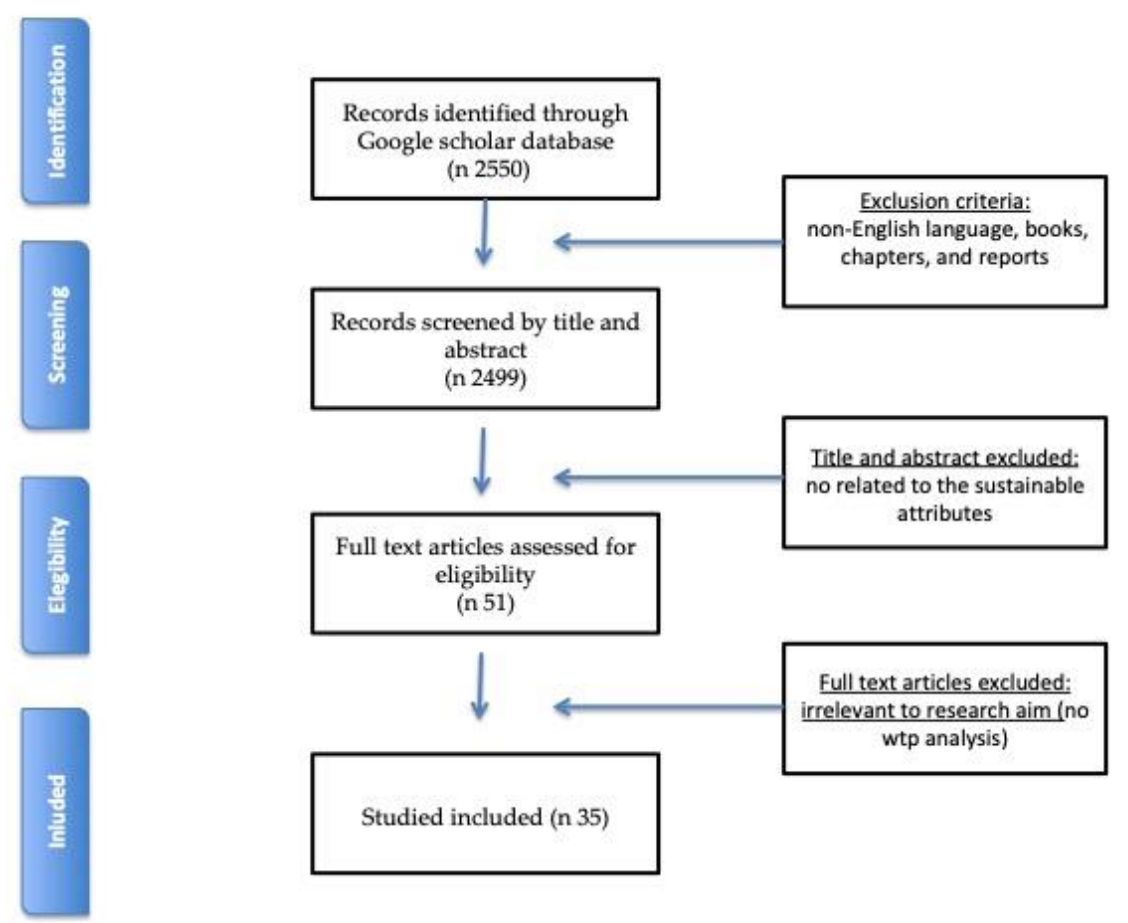

Figure 1. Flow chart diagram visualizing the database literature searching procedure. The exclusion criteria are indicated. (Source: authors).

The literature searching criteria were implemented using a combination of keywords. The keywords, "sustainable", "seafood", and "fish" were used with the following terms: "choice", consumers", "behaviour", "behavior", "preferences", "willingness to pay", and "wtp".

The first set of keywords was used to limit the search to studies that consider sustainable fish and seafood, while the second group was used to identify the studies based on consumer preferences and willingness to pay for credence attributes.

Figure 1 shows a flowchart diagram of the database searches and the exclusion criteria followed. The search firstly resulted in a total of 2550 records. The screening process for selecting the relevant literature was conducted in two stages: Screening and Eligibility.

In the Screening phase, the selected papers were screened and decreased in number to 2499 by applying the primary exclusion criteria. Only papers written in English and published in an indexed journal were included in this study [16]. Next, in the Eligibility stage, articles were selected on the basis of the information present in the title and in the abstract. The examination of the abstracts led to the elimination of some articles that were not focused on consumers' behavior or did not consider this in relation to sustainable fish products. In this stage, the number of papers was narrowed down to 51 for the review. Next, in the Inclusion stage, each article was also further reviewed on the basis of the information in the full text in order to decide if each study fits the eligibility criteria of the review. Finally, after the exclusion of irrelevant papers on the basis of their aims, a sample of 35 papers was selected to examine our research question in the categorization and analysis stage.

Several studies investigated more than one attribute or more than one item or were carried out in more than one country. Therefore, the sum of the figures related to willingness to pay (WTP) is greater than 35 (63 WTP).

The attributes related to sustainability investigated in the literature included in this review are categorized in Table 1. 
Table 1. Attributes related to sustainability selected for the review.

\begin{tabular}{cl}
\hline \multicolumn{1}{c}{ Variable } & \multicolumn{1}{c}{ References } \\
\hline \multirow{2}{*}{ Animal welfare } & Olesen, et al., 2010 [18]; Davidson et al., 2012 [19]; Solgaard and Yang, 2011 [20]; \\
& Grimsrud et al., 2013 [21]; Zhou et al., 2016 [22]; Zander and Feucht, 2018 [23] \\
\hline & Johnston et al., 2001 [24]; Johnston et al., 2006 [25]; Whitmarsh et al., 2006 [26]; \\
& Erwann, 2009 [27]; Ariji et al., 2010 [28]; Goyert et al., 2010 [29]; \\
& Rhoeim et al., 2011 [30]; Xu et al., 2012 [31], Fernández et al. 2013 [32]; \\
& Sogn Grundvåg et al., 2013 [33]; Sogn Grundvåg et al., 2014 [34]; \\
& Uchida et al., 2014 [1]; Uchida et al., 2014 [35]; Asche et al., 2015 [36]; \\
& Blomquist et al., 2015 [37]; Fonner and Sylvia, 2015 [38]; Lim et al., 2015 [39]; \\
& Bronnmann et al., 2016 [40]; Chen et al., 2015 [41]; Salladarrè et al., 2016 [42], \\
& Rickertsen et al., 2017 [43]; Sun et al., 2017 [44]; Vitale et al., 2020 [45] \\
\hline \multirow{2}{*}{ Eco-labels } & Sogn Grundvåg et al., 2013 [33]; Sogn Grundvåg et al., 2014 [34] \\
\hline Line-caught fish & Defrancesco, 2003 [46]; Disegna et al., 2009 [47]; Olesen, et al., 2010 [18]; \\
& Stefani, et al., 2012 [48]; Xu et al., 2012 [31]; Mauracher et al.,, 2013 [49]; \\
& Asche et al., 2015 [36]; Isaac et al., 2015 [50]; Ankamah et al., 2016 [51]; \\
& Chen et al., 2015 [41]; Zander and Feucht, 2018 [23] \\
\hline Organic & Davidson et al., 2012 [19]; Stefani, et al., 2012 [48]; Mauracher et al., 2013 [49]; \\
& Asche et al., 2015 [36]; Fonner and Sylvia, 2015 [38]; Lim et al., 2015 [39]; \\
& Zander and Feucht, 2018 [23] \\
\hline \multirow{2}{*}{ Origin } & Davidson et al., 2012 [19] \\
\hline Wild-caught fish &
\end{tabular}

\subsection{Overview of Selected Papers}

Information relating to the author(s), year of publication, country(s) where the study was carried out, type of product analyzed, attribute investigated, and willingness to pay found in the papers selected for this literature review are summarized in Table S1 (Table in Supplementary Materials).

The attributes related to sustainability investigated in the selected papers are presented in Figure 2.

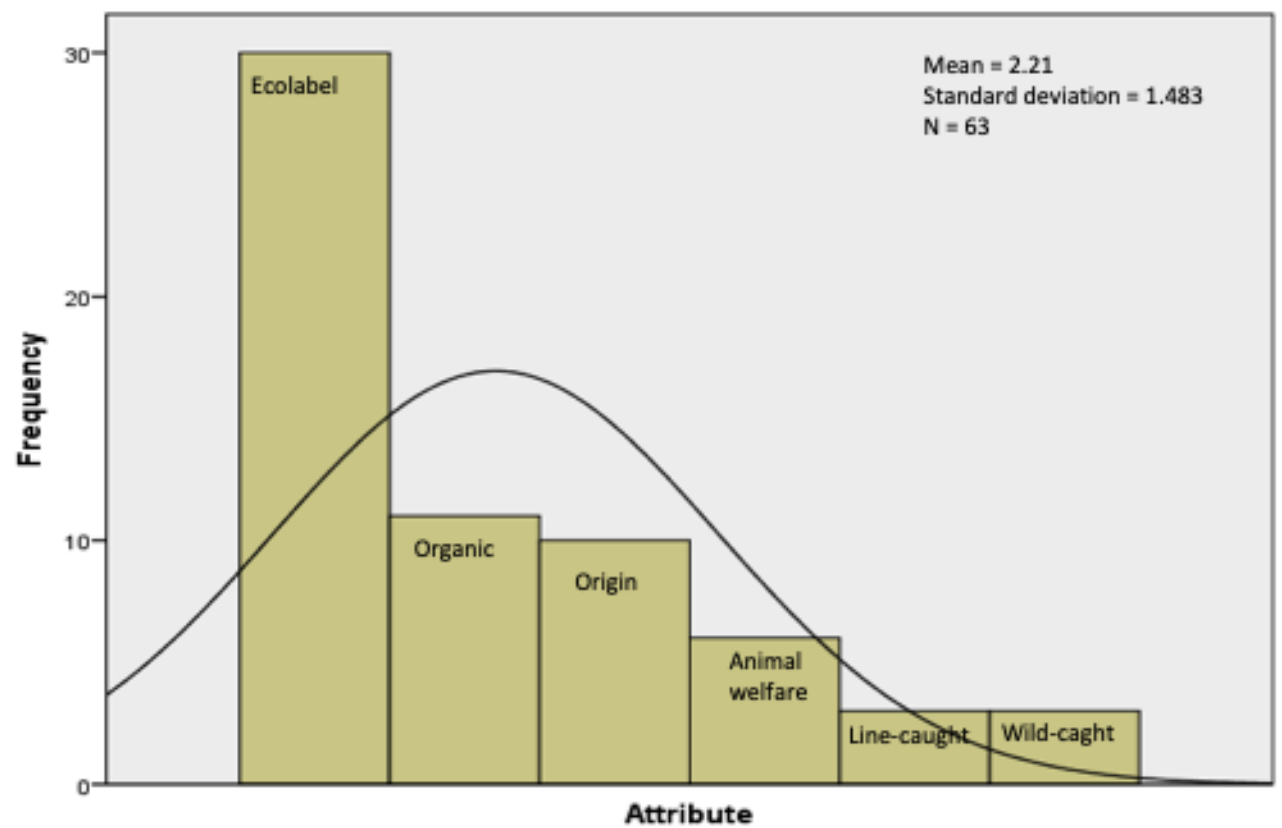

Figure 2. Attributes investigated in the selected papers (Source: authors' elaboration). 
A large number of studies analyzed in this paper considered fish and seafood as a unique and undifferentiated food category, while the remaining studies focused on one or more specific fish products, such as salmon, monkfish, pangasius, sole, haddock, sea bream, trout, tuna, cod, crab, swordfish, tilapia, shrimp, moi, lobster, flounder, bass, and anchovy.

The number of selected papers on the topic under investigation per year from 2000 to 2020 is shown in Figure 3.

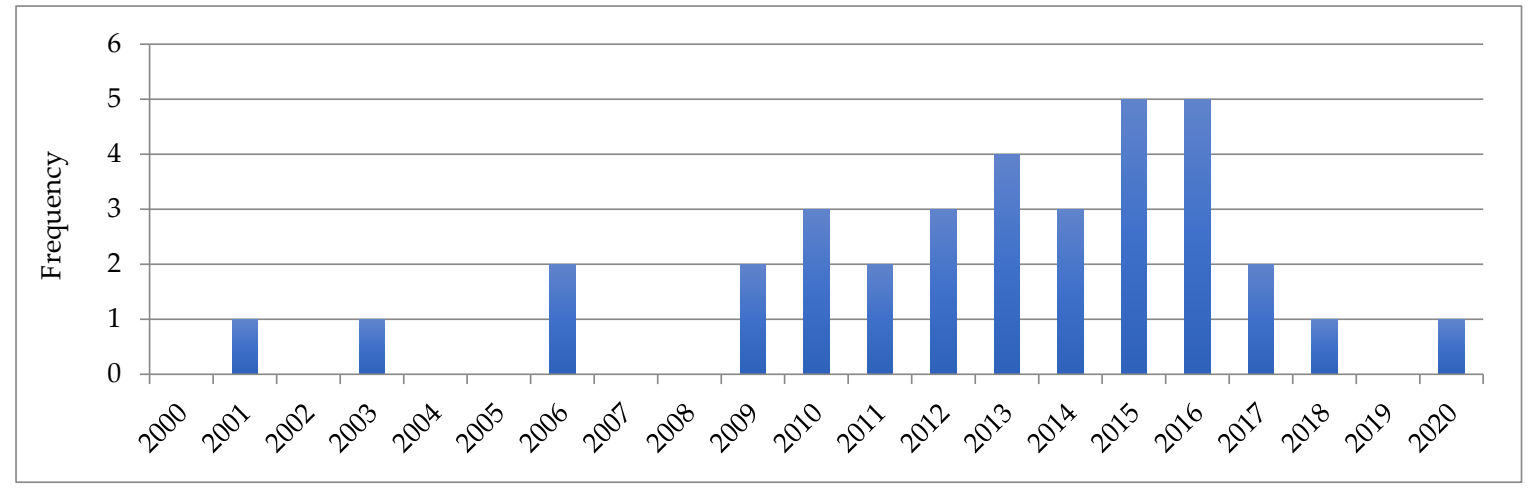

Figure 3. Number of papers per year (2000-2020) (Source: authors' elaboration).

The studies analyzed in this review were carried out worldwide. Figure 4 shows an overview of the countries where the selected studies were carried out: 39 studies were from in European countries, including the United Kingdom (14), Italy (11), France (12), Germany (5), Spain (5), Norway (4), Finland (4), Ireland (4), Poland (4), Denmark (3), and Sweden (1); 19 studies were conducted in the USA; and the rest were from Asia: China (2) and Japan (3).

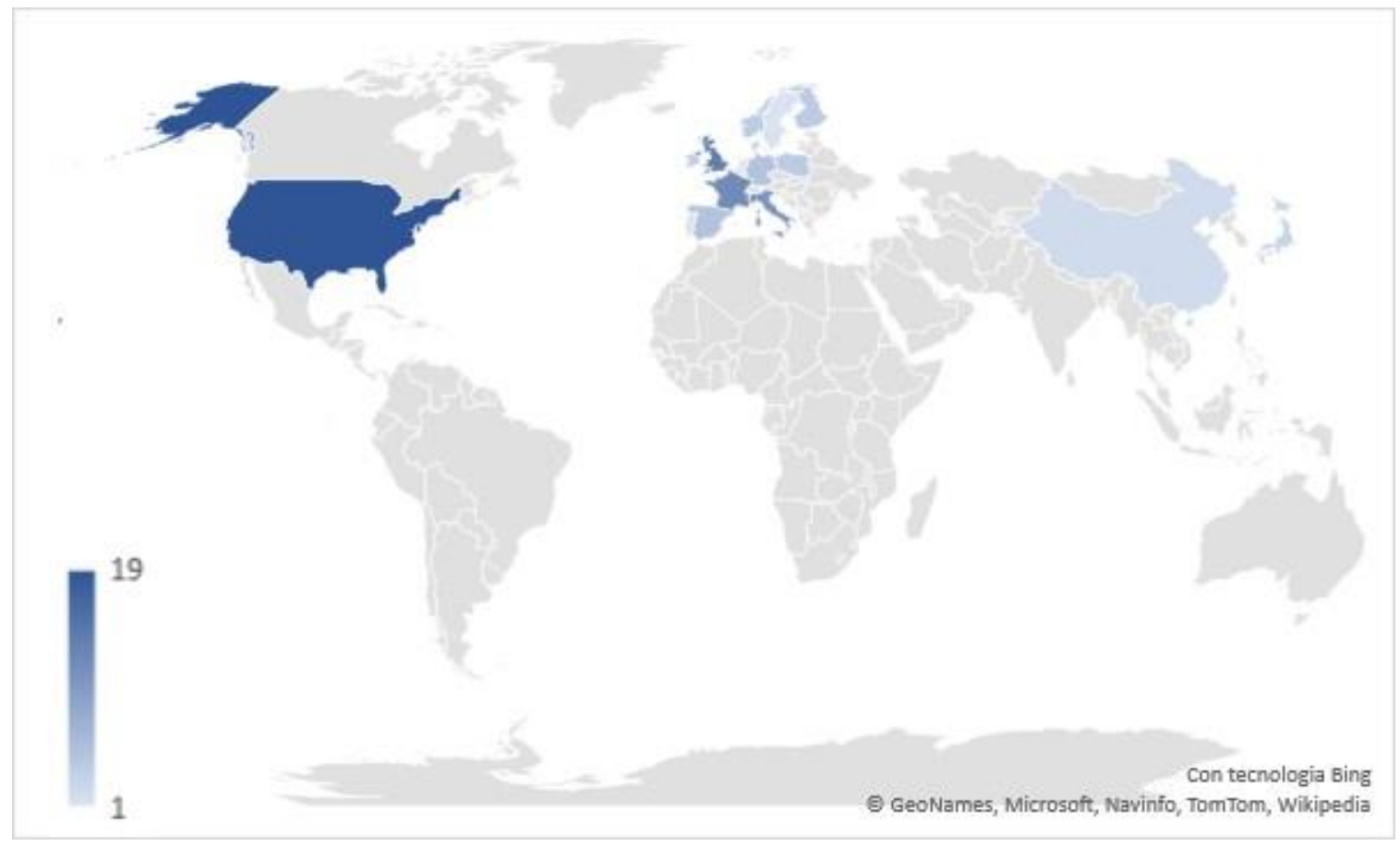

Figure 4. Area where the selected studies were conducted (Source: authors' elaboration). 


\subsection{Statistical Analysis}

In this study, we analyzed the credence attributes of sustainable fish products and consumers' willingness to pay for these in the literature.

We used the WTP reported in the 35 articles. We define a WTP measure in terms of an extra percentage that consumers are willing to pay over the base price. Additionally, it is important to point out that the final number of WTP measures identified (final number $=63$ ) is larger than the number of studies included (number included $=35$ ), since some of the papers report multiple WTP estimates due to there being multiple products, multiple attributes, and/or multiple areas analyzed in each article.

The independent variables used in the model estimation (Table 2), have concerned the credence attributes for sustainable fish products (organic, country of origin, eco-labels, animal welfare, wild caught fish and line-caught fish) and the Countries analysed in the model (China, Denmark, Finland, France, Germany, Ireland, Italy, Japan, Norway, Poland, Spain, Sweden, United Kingdom and USA). The dependent variable is the WTP for each fish attribute. The average and standard deviation of each variable (dependent and independent) are determined in order to statistically highlight its relative importance.

Table 2. Summary statistics and definitions of independent variables.

\begin{tabular}{|c|c|c|c|}
\hline Variables & Description & Mean & $\begin{array}{l}\text { Standard } \\
\text { Deviation }\end{array}$ \\
\hline \multicolumn{4}{|c|}{ Dependent variable } \\
\hline WTP & $\begin{array}{l}\text { Willingness To Pay per each fish attribute } \\
\text { Independent variable }\end{array}$ & $29,073 \%$ & $41,166 \%$ \\
\hline China & 1 if data from China; 0 otherwise & 0.032 & 0.177 \\
\hline Denmark & 1 if data from Denmark; 0 otherwise & 0.048 & 0.215 \\
\hline Finland & 1 if data from Finland; 0 otherwise & 0.063 & 0.246 \\
\hline France & 1 if data from France; 0 otherwise & 0.190 & 0.396 \\
\hline Germany & 1 if data from Germany; 0 otherwise & 0.079 & 0.272 \\
\hline Ireland & 1 if data from Ireland; 0 otherwise & 0.063 & 0.246 \\
\hline Italy & 1 if data from Italy; 0 otherwise & 0.175 & 0.383 \\
\hline Japan & 1 if data from Japan; 0 otherwise & 0.048 & 0.215 \\
\hline Norway & 1 if data from Norway; 0 otherwise & 0.063 & 0.246 \\
\hline Poland & 1 if data from Poland; 0 otherwise & 0.063 & 0.246 \\
\hline Spain & 1 if data from Spain; 0 otherwise & 0.079 & 0.272 \\
\hline Sweden & 1 if data from Sweden; 0 otherwise & 0.016 & 0.126 \\
\hline United Kingdom & 1 if data from United Kingdom; 0 otherwise & 0.222 & 0.419 \\
\hline USA & 1 if data from USA; 0 otherwise & 0.302 & 0.463 \\
\hline Organic & 1 if the related WTP was estimated; 0 otherwise & 0.175 & 0.383 \\
\hline Country of origin & 1 if the related WTP was estimated; 0 otherwise & 0.127 & 0.336 \\
\hline Eco-labels & 1 if the related WTP was estimated; 0 otherwise & 0.286 & 0.455 \\
\hline Animal welfare & 1 if the related WTP was estimated; 0 otherwise & 0.095 & 0.296 \\
\hline Wild caught fish & 1 if the related WTP was estimated; 0 otherwise & 0.048 & 0.215 \\
\hline Line-caught fish & 1 if the related WTP was estimated; 0 otherwise & 0.048 & 0.215 \\
\hline
\end{tabular}

Moreover, we estimated a regression model in which the dependent variable is the WTP defined as an extra percentage of the price that consumers are willing to pay for the purchase of sustainable fish products compared to the base price. Instead, the independent variables refer to the credence attributes for the same products. The results of the estimated regression model show that Origin has significantly influenced consumers' WTP in the past studies while other attributes are not statistically significant. The estimate of the econometric model highlights the greater attention paid by the consumer to origin, representing the credence attributes for sustainable fish product most appreciated by the consumer (Table 3). 
Table 3. Regression results.

\begin{tabular}{cccccc}
\hline \multirow{2}{*}{ Variable } & \multicolumn{2}{c}{ Non-Standardised Coefficients } & $\begin{array}{c}\text { Standardised } \\
\text { Coefficients }\end{array}$ & t & Sig. \\
\cline { 2 - 4 } & $\mathbf{B}$ & Standard Error & Beta & & \\
\hline Costant & 27,321 & 10,640 & & 2.568 & 0.013 \\
Organic & -1312 & 16,040 & -0.012 & -0.082 & 0.935 \\
Origin & 38,979 & 17,644 & 0.318 & 2.209 & $0.031^{* *}$ \\
Eco-labels & $-12,321$ & 14,186 & -0.136 & -0.869 & 0.389 \\
Animal welfare & 229 & 19,426 & 0.002 & 0.012 & 0.991 \\
Wild-caught fish & 20,912 & 25,328 & 0.109 & 0.826 & 0.413 \\
Line-caught fish & -9788 & 25,328 & -0.051 & -0.386 & 0.701 \\
\hline Model & Sum of & df & Mean of & F & Sig. \\
\hline Regression & $16,312.663$ & 6 & Squares & & 0.134 \\
Residue & $88,752.921$ & 56 & 2718.777 & 1.715 & \\
Total & $105,065.584$ & 62 & 1584.874 & & \\
\hline
\end{tabular}

\section{Results of Literature Review}

\subsection{Country of Origin}

The literature is full of contributions that provide evidence on the key role of the country of origin in consumer choices of fish products. The country of origin emerged as one of the most relevant fish attributes in relation to consumer choices [13,48,49,52-54].

Consumers prefer domestic over imported fish products [55], and this attribute emerged as the most important attribute in relation to choosing fish, and products with this attribute gained a high premium price, compared to other attributes related to sustainability [52].

Interestingly, the studies focused on the WTP for organic and local production found that consumers are willing to pay a higher premium price for local production than for organic production, giving more importance to the origin than to the production method [56].

In a study conducted on Hawaiian consumers, Davidson et al. [19] found that consumers prefer domestic fresh fish from Hawaii, and they are willing to pay a premium price of $39.2 \%$ and $43.7 \%$ for local moi and tilapia, respectively [19]. Additionally, in Italy, in the same year, the country of origin emerged as an important element of consumer choices, and consumers showed a relevant willingness to pay a premium price of $329 \%$ for the origin of sea bream [48]. In 2013, in the same country, Mauracher et al. [49] confirmed the past finding for Italian consumers, showing that the respondents in their study were concerned about the place of origin of seafood products. They estimated a willingness to pay a premium price of $50 \%$ for farmed sea bass produced domestically.

In the USA, Fonner and Sylvia [38] showed that consumers prefer domestic seafood products over the imported alternative and found that they are willing to pay a premium price of $27.2 \%$ for local crab and $21 \%$ for local salmon. In the USA, Lim at al. [39], in line with the study carried out in the same year and country by Fonner and Sylvia [38], found that consumers are willing to pay a premium price of approximately $42.5 \%$ for the origin label of seafood products.

The findings of Asche et al. [36] are also in line with a previous study on consumer preferences regarding the origin of seafood products. The authors, using a unique dataset of salmon prices in different retail chains in the United Kingdom, discovered that consumers are willing to pay a $4 \%$ premium price for the origin label of seafood products.

In a more recent study, Zander et al. [23] studied European consumers from different EU countries and found an average premium price of $9.4 \%$ for the country of origin label of fish and seafood products. 


\subsection{Organic}

The studies identified an overall positive perception towards organic fish products. However, despite the fact that there is a willingness to pay a premium price for organic fish products, organic labels do not play a main role in consumer choices of fish products, compared with other attributes, such as the country of origin [56].

The study carried out in Italy by Defrancesco [46] showed that Italian consumers are willing to pay a premium price of $40 \%$ for organic-labelled seafood products. The $43 \%$ of interviewed households accepted the proposed premium price. The percentage of acceptance to pay declined according to the increase in the proposed amounts (ranging from $71.6 \%$ for a premium less than $10 \%$ to $16.6 \%$ for a price increase of over $80 \%$ ).

The authors also found that as the percentage of the price premium increases, their probability to accept the proposed amount decreases, and the amount of premium accepted is positively related to socio-demographic characteristics, such as the income level of respondents.

Another study conducted in Italy by Disegna et al. [47] revealed similar findings. According to their results, Italian consumers were willing to pay an average premium price of $46 \%$ for organic trout, compared to the conventional alternative.

Olesen et al. [18] carried out a study in Norway using a non-hypothetical choice experiment. The authors discovered that Norwegian consumers are willing to pay a premium price of $15 \%$ for organic salmon, compared to the conventional one.

In China, Xu et al. [31] showed that Chinese consumers are willing to pay a 7-9\% premium price for organic-labelled seafood products in general.

Stefani et al. [48], in Italy, estimated that Italian consumers are willing to pay a relevant premium price of 50\% for organic sea bream. Another study [49] carried in the same country confirms the previous results, finding that Italian consumers have a positive perception regarding organic seafood, and they are willing to pay a $36 \%$ premium price for organic-labelled sea bass.

Asche et al. [36], in the UK, using a dataset of salmon prices in different retail chains, also found a positive behavior towards organic-labelled seafood products. They found that consumers in the UK are willing to pay a $25.3 \%$ premium price for organic-labelled salmon. In the same year, in Denmark, Isaac et al. [50] using the hedonic price method, investigated consumer preferences in relation to organic seafood products, finding that Danish consumers are willing to pay a $20 \%$ price premium for organic-labelled salmon.

Chen et al. [41] conducted a study in France in order to investigate consumers' willingness to pay for organic seafood products and found a premium price of $11 \%$ for organic-labelled fish. The higher premium for the organic label may be explained by the higher degree of familiarity with this label: $61 \%$ and $32 \%$ of the participants claimed to have seen the organic label "often" and "sometimes", respectively. Moreover, the results of the study showed that organic fish farming could be a good market opportunity for improving consumer information on organic products, adopting a supply concentration strategy at the farm level, and carefully managing a semi-extensive-farming set up by proposed regulations.

Ankamah et al. [51] carried out a study in Denmark to identify the price premium for organic salmon in Danish retail sales using consumer panel scanner data from households. According to their results, by applying a random effect hedonic price model, which permits an unobserved household heterogeneity, a price premium of $20 \%$ was identified for organic salmon.

In recent years, Zander and Feucht [23] confirmed the previous finding in the literature on this topic, finding that European consumers from different EU countries are willing to pay a $14.8 \%$ premium price for organic fish and seafood.

\subsection{Animal Welfare}

In addition to the environmental and maintenance of natural resources concerns, animal welfare is also gaining attention in the fish sector. In recent years, concerns about animal welfare have increasingly 
gained weight in public opinion. Consumers consider animal welfare to be an important issue in general, but they are often not necessarily willing to change their consumption choices [57].

Interestingly, even if consumers are concerned about animal welfare, most of them do not perceive animal welfare as their own responsibility [58] and consider it the responsibility of producers or governmental authorities to adopt appropriate animal welfare regulations [58].

Olesen et al. [18] carried out a non-hypothetical choice experiment in Norway in order to examine the consumers' willingness to pay for animal-welfare-labelled salmon. The authors found that Norwegian consumers are concerned about animal welfare and are willing to pay a $17 \%$ premium price for welfare-labelled salmon.

Using a contingent valuation method in order to evaluate Danish consumers' willingness to pay for fish welfare, Solgaard and Yang [20] found that consumers are willing to pay a $25 \%$ premium price for welfare-farmed rainbow trout with the animal welfare attribute.

Grimsrud et al. [21], using a choice experiment to estimate the willingness to pay for the improved welfare of farmed salmon, discovered similar results to those found in the same country by Olesen et al. [18]. According to the authors, Norwegian consumers are willing to pay a $15 \%$ premium price and accept tax increases for animal welfare improvements in farmed seafood.

More recently, Zander and Feucht [23] conducted a study in several European counties and found an average premium price of $14 \%$ for the animal welfare label in the seafood sector.

In fishing practice, turtles are often injured or killed through by-catch. Voluntary third-party certification programs, such as the labels "turtle safe", aim to bridge the information gap between producers and consumers on sustainability concerns, such as animal welfare. The "Turtle-safe" certification was defined as "fish harvested by fisheries under stringent controls to avoid sea turtle by-catch", and it implies that fishermen have avoided this collateral damage.

Davidson et al. [19], in the USA, investigated the attribute, "turtle safe", for tuna as a hypothetical feature designed to gauge consumers' environmental concern when purchasing fish products. The authors showed that consumers are willing to pay a premium price of $31.3 \%$ for the "turtle safe" hypothetical attribute certifying that the tuna was caught under stringent controls to avoid sea turtle by-catch.

Zhou et al. [22], in the USA, found that consumers are willing to pay a $63 \%$ premium price for tuna labelled as "Certified Turtle Safe". In addition, they highlight the socio-demographic correlation, showing that tuna labelled as "Certified Turtle Safe" is more likely to be purchased by male and younger consumers.

The role of the effect of turtle safe certification in consumer choice is still under-investigated in the literature. The limited number of papers on this topic suggests the need for further research.

Since the studies on this topic are quite limited, and ethical values about fish welfare are not fully investigated and understood, further research on consumers' willingness to pay for improved fish welfare are needed [21].

\subsection{Eco-Labels}

Several studies discovered that consumers have a positive perception of and show a willingness to pay a premium price for eco-labelled fish products [30,36,49].

Eco-labels provide important information to consumers, enhancing their awareness of ecological and environmental features in purchasing fish products [12].

In the study carried out by Johnston et al. [24], a price premium of $27 \%$ and $22 \%$ in the USA and Norway for eco-labelled shrimp and cod was found, respectively.

Whitmarsh and Wattage [26] conducted a study in the U.K. in order to investigate consumer preferences for eco-labels in the seafood sector and found that consumers are willing to pay a premium price of $22 \%$ for eco-labelled farmed salmon. In the same year, Johnston et al. [25] carried out a study in the USA in order to estimate the willingness to pay for eco-labelled fish. The authors revealed a premium price of $31 \%$ for swordfish, $41 \%$ for flounder, and $50 \%$ for salmon. 
Erwann [27], using a logit model, conducted a study in France in order to investigate the role of eco-labels in fish preferences and showed that consumers are willing to pay a $10.9 \%$ premium for eco-labelled pollack.

Ariji [28] studied Japanese consumers and found a positive perception of eco-labelled fish products and a willingness to pay a $24 \%$ premium price for eco-labelled tuna.

$\mathrm{Xu}$ et al. [31] found that Chinese consumers accepted to pay a small premium price of $5 \%$ for eco-labelled seafood products.

Fernández et al. [32], studying consumer preferences for seafood products in Spain, discovered that consumers are willing to pay a $32 \%$ premium price for eco-labelled sea bream.

Sogn-Grundvåg et al. [34], in the UK, showed a premium price of $12.7 \%$ for eco-labelled cod, haddock, and pollock. In the same year, Uchida et al. [1] revealed that Japanese consumers are willing to pay a 37\% premium price for eco-labels and that eco-labelled products are preferred compared with un-labelled products. This percentage is higher than the premium price for the same country found by Ariji [28].

In 2015, Blomquist et al. [37] conducted a study in Sweden and found that, despite the positive perception regarding eco-labels, consumers showed a slight willingness to pay a premium price of $7 \%$ for eco-labelled cod, compared to the conventional alternative.

Fonner and Sylvia [38], in the USA, found that consumers are willing to pay a $26.8 \%$ premium price for eco-labelled crab and 21.6\% for eco-labelled salmon. In France, Salladarré et al. [42] showed that consumer are willing to pay a $6 \%$ premium price for eco-labelled monkfish, a $10 \%$ premium price for eco-labelled sole, and a 15\% premium price for eco-labelled lobster. In addition, the authors found that premium price is positively related to socio-demographic characteristics, such as income level, in accordance with microeconomic theory. In the same year and country, Chen et al. [41] conducted a stated choice experiment in France and found that there are positive eco-labelling effects on the willingness to pay (WTP) for fish. The average French consumers are willing to pay an overall premium price of about $4 \%$ for eco-labelled fish. Interestingly, only $10 \%$ and $30 \%$ of the participants claimed to have seen the MSC label "often" or "sometimes", respectively, before the experiment.

Sun et al. [44], in the USA, found that American consumers are willing to pay a 13\% premium price for eco-labelled tuna, compared to the conventional alternative. Rickertsen et al. [43], in France, showed that consumers are willing to pay a $15 \%$ and $24 \%$ premium price for eco-labelled monkfish and cod, respectively.

In a more recent study, Vitale et al. [45] found that Italian consumers are willing to pay a $20 \%$ premium price for eco-labelled anchovy.

The eco-label best known to consumers is the Marine Stewardship Council (MSC) label. The MSC is the international program for the certification of sustainable and well-managed fisheries, aiming at a standard of sustainability and, consequently, eco-labelling [59]. The MSC label certifies fisheries according to three principles: sustainable fish stocks (i.e., avoiding overfishing), minimizing environmental impact (e.g., limiting destructive fishing gear and by-catch), and effective management. Nowadays, the MSC represents one of the most popular eco-certifications in the fish industry, providing relevant information to consumers, with the aim of having consumers purchase fish products from fisheries whose management is certified as sustainable [40]. Several studies investigated the role of MSC eco-certification in consumer choices of sustainable fish. According to previous studies, consumers show a positive perception of the MSC certification and are willing to pay a premium price for this type of eco-label.

In order to evaluate whether the costs of the Maine lobster fishery certification are recognized as beneficial, Goyert et al. [29], in the USA, carried out a study to understand consumer attitudes and purchasing preferences related to MSC eco-labelled lobster. The authors showed that consumers are willing to pay a $37 \%$ premium price for MSC eco-labelled lobster, compared to the conventional alternative. 
Roheim et al. [60] carried out a study using a hedonic analysis of MSC eco-certified frozen processed Alaska pollock products using scanner data in the UK chains. The authors found a $14.2 \%$ premium price for the eco-labelled MSC Alaskan Pollock.

Sogn-Grundvåg et al. [33] using the hedonic price model, conducted a study in the UK and found that consumer have a positive perception of and are willing to pay a $10 \%$ premium price for MSC-labelled haddock.

Uchida et al. [35] used a second price auction in order to investigate Japanese consumers' willingness to pay for MSC-labelled fish products. The authors found that when consumers are provided information on both the status of fish stocks and the benefit of the MSC program, a premium ranging from $14.4 \%$ to $25.8 \%$ for MSC eco-labelled salmon was paid. Interestingly, they also discovered that when only information about the purpose of MSC program was provided, i.e., without simultaneously providing information about the need for the MSC program, this was not sufficient to generate a statistically significant premium for the MSC label.

Asche et al. [36], using a unique dataset of prices in UK supermarket chains, conducted a study in order to investigate whether pricing varies across different eco-labels and to what extent different retailers charge different prices. The authors found that there is a premium price for eco-labels. In particular, the MSC label received an average price premium of $13.1 \%$ for MSC-labelled salmon. The MSC premium is very close to the $14.2 \%$ reported for Alaska Pollock by Roheim et al. [30] and the $10 \%$ and $12 \%$ reported for haddock and whitefish, respectively, by Sogn-Grundvåg et al. [33,34]. However, the results show that eco-label price premiums vary across retail chains. Specifically, MSC-labelled salmon has a high premium in low-end retail chains but no statistically significant premium in high-end chains.

Lim et al. [39], in a study carried out in the USA, found that consumers are willing to pay a $29 \%$ premium price for MSC-labelled canned tuna. Interestingly, the results show that the MSC certification generates an overall positive effect on consumer preferences for imported tuna, indicating country-specific effects. However, the study is limited to the USA population and canned products; therefore, the outcomes are unlikely to be fully generalizable to other markets and products.

The study carried out by Bronnmann et al. [40], using a hedonic price function, highlighted a positive perception of MSC labels for fish products in Germany. However, the results indicated a small price premium for MSC-labelled fish products. The authors found that consumers are willing to pay a $4 \%$ premium price for MSC-labelled salmon.

The difference between the premium prices for MSC-certified fish products in the different studies reveals that there are substantial differences between countries [24].

\subsection{Wild-Caught Fish}

Nowadays, the high demand for fish and fish products and, consequently, overfishing have damaged fish stocks and the marine ecosystem.

In response to this situation, an alternative way to preserve the supply of wild-caught fish has been proposed, i.e., aquacultures or farm-raised fish [61]. It is worth noting that the benefits of aquacultures include a lower cost and year-round availability, compared to wild-caught fish [62]. However, according to previous studies, consumers prefer wild-caught fish due to the higher quality perception, better taste [63], and absence of negative environment impacts, which characterize aquaculture practice [61].

The study carried out in the USA by Davidson et al. [19] analyzed Hawaiin consumers' willingness to pay for farmed vs. wild-caught attributes, using a conjoint analysis of four different fish species (tuna, salmon, tilapia, and moi pacific threadfin). The respondents cited taste as the most important reason for preferring wild-caught fish production to both land-based and marine-based aquaculture production. Concern about the use of natural resources is a driver for some respondents in purchasing wild-caught fish and the main driver for other respondents in purchasing fish from marine aquaculture production. Of the 17 respondents who preferred land-based aquacultures, six favored it because of taste preferences, 
and five participants were concerned about environmental pollution from other production methods. The authors found that Hawaiian consumers are willing to pay an overall relevant premium price for wild-caught fish over the farm-raised option. In particular, they showed a willingness to pay a $55.8 \%$ premium price for wild-caught salmon and $63.5 \%$ and $25.4 \%$ for wild-caught tuna and moi, respectively. According to the results, wild-caught fish products are preferred over farm-raised fish mainly for its better taste among Hawaiian consumers, as was previously found by O'Dierno et al. [63].

The premium price found for wild fish products confirms that consumers place a high value on maintaining wild fish stocks. The adoption of appropriate initiatives to promote and develop the sector is an advantage for both fishermen and fish farmers. Sustainability-related attributes of beliefs can be developed into niche marketing strategies [19].

Nevertheless, the very small number of papers in the literature on the effect of the wild-caught attribute on consumer choices suggests the importance of and need for further research on this topic.

\subsection{Line Caught Fish}

Products labelled as sustainable or responsibly sourced, as in the case of "line-caught" fish, represent one of the most important sustainable techniques, with a low environmental impact. In the last decade, consumer concerns about the state of fish stocks and how fish have been captured, among different capturing methods, has been growing [33,34]. Nevertheless, despite the importance of this attribute, there appears to have been little research on this topic and small price premiums for fish products marketed as responsibly sourced, such as the line-caught attribute.

The first study in the literature to investigate whether the line-caught attribute commands any price premium at the supermarket level of the value chain was carried out by Sogn-Grundvåg et al. [33]. The analysis was based on weekly observations of chilled pre-packed cod and haddock in seven different supermarkets in the UK. The results of the study highlighted that "line-caught" cod and haddock received a price premium of $18 \%$ and $10 \%$, respectively.

In the same country, the same authors [34], analyzing the same items and using the hedonic price model, examined the price premiums for the same attribute, "line-caught". They found that the premium was higher than that discovered in previous studies [33]. The authors show a price premium of $24,6 \%$ for the "line caught" fishing method, compared to conventional products based on fish captured by other types of gear, mainly trawling. However, the effect of the line-caught attribute on consumer choices requires further research due to the limited number of papers in the literature on this topic.

\section{Discussion}

The demand for certified products appears adequate to support the continued existence of certification schemes. The study identifies the credence attributes related to the sustainability of fish products and the relative price premium percentage estimated in the literature in order to draw conclusions on this topic. The price premium estimates indicate the importance that consumers place on externalities, considering that they are willing to pay a premium price for eco-labelled products.

The investigation identifies the credence attributes used in the literature for this study and compares the WTP estimates of some of the papers in order to draw conclusions on this topic.

The WTP estimates show that consumers are willing to pay premiums for domestic products simply because they are local [64]. In several studies, the more significant effects on consumer choice derives from the country of origin label. According to the results, the general pattern shows that the origin was found to be the most important attribute in consumer choices and received the highest price premium [39,48,49]; in particular, local products are the preferred choices $[19,23,32,35,39,48,49]$.

The importance of country of origin preferences might be due to several factors. Consumers perceive fish and seafood as highly perishable products, compared to other agro-food products, and they value the freshness attribute more than any other quality attribute. Therefore, a shorter transportation distance of products plays an important role not only in relation to environmental impact, but also in 
relation to consumer preferences regarding local fish products [65]. Additionally, some geographical areas have unique and typical conditions due to the local environment or typical processing traditions, which cause product quality to be particularly valued and considered in fish markets. Furthermore, consumers are worried about the safety of fish products, especially when products are imported from foreign countries, where food regulations are perceived to be inadequate [66]. The results in the literature indicated a high percentage of price premiums for local fish products, compared to imported alternatives, because of food safety issues [67]. Other reasons for consumer preferences regarding the origin of fish products could be that more trust is placed in local products or the ethnocentrism of consumers [68].

Even studies in the literature on wild-caught fish preferences in consumer choice have shown positive effects worldwide, receiving a high WTP [69]. Overall, consumers prefer wild-caught fish due to its higher safety [43], better quality, and taste perception [64] than the farm-raised alternative.

The results also show that consumers are concerned about animal welfare [23]. Several studies have indicated that consumers have a positive perception and willingness to pay a slight premium price for improved fish welfare [18] and also to avoid by-catch, preferring the eco-label, "turtle safe" [19,22].

With regard to organic labels, studies in the literature identify a positive organic price premium for fish products in general. However, despite the fact that the organic attribute is appreciated by consumers, it does not play a major role in consumer choices of fish products, compared with other attributes, such as the country of origin label. This result is possibly due to the fact that consumers probably perceive fish and seafood as products that are definitely healthy and thus do not evaluate the residues of chemical feed additives used in aquaculture practice. However, organic labels receive a higher WTP, compared to eco-labels. One possible explanation for this might be that organic labels are well recognized, and consumers understand them, while they may have less knowledge on specific fish eco-labels, like the MSC. This can be backed up by the finding of Grunert et al. [70], who found that most consumers only have a limited use of sustainability labels, which might well include the well-known organic label and exclude specific fish labels, like MSC.

Based on the results, in several studies, the effect of certification is shown to be relevant when presenting information about the meaning and the consequence of specific certifications, since this information is shown to increase the WTP.

In this regard, it is important to underline that, as indicated by Roheim et al. [30], the price premiums estimated in previous studies should be considered conservatively, as the values could be relatively high due to the hypothetical nature of some of the examined studies. Moreover, the analyzed studies are heterogeneous, because they are characterized by several distinctive features, such as the variety of products analyzed, year and countries where the studies were carried out, attributes included in the experiment, and technical characteristics of the samples. Therefore, in general, the amounts need to be considered as simple indicators of the relative importance of each analyzed attribute.

\section{Conclusions}

In consideration of the current concern for sustainability in the fish sector, there is a growing interest in the potential use of product differentiation through sustainable labelling, as a tool for promoting the sustainable management and exploitation of fish stocks.

One of the most interesting results is the impact of the country of origin attribute in consumer fish choice, which receives the highest premium price. This can be explained by the fact that consumers prefer local over imported food [71]. Therefore, we suggest that producers invest in the local market and highlight the origin of the fish product on the package.

Selling domestic products in local markets is more appreciated by consumers, and at the same time, it means lower supply chain costs for producers, but also a lower potential for environmental damage [49,52].

The WTP estimated in the literature shows the importance that consumers place on externalities related to the environment, considering that they are willing to pay a premium price for sustainably 
sourced products. Thus, producers that use alternative production methods that somehow reduce the contamination of the environment should explicitly add this information to the product labels, even if the information is already implied by a certification, because consumers may pay premiums for this extra information.

Labels related to sustainability are becoming an important attribute of fish choice, and studies in the literature found that, overall, consumers are willing to pay a premium price for sustainability-labelled fish products [30,49]. These labels add value to products and provide relevant information about sustainability in the fish sector, reducing the lack of consumer awareness regarding sustainable fish products.

Nowadays, new market opportunities for sustainable fish and labelling to differentiate fish products in an increasingly international and more competitive market are growing.

Consumers can use this information to change their purchasing choices towards a more sustainable behavior [72]. However, the benefits of the sustainable management of marine environment are still inadequately communicated to consumers, and consumers often have limited knowledge of production processes and a lack of insight into the implications of their food purchase decisions for the food supply chain [73].

Gutiérrez and Morgan [74] stress that sustainability issues should motivate consumers in their purchasing choices, but they should not become a complex matter for them. They should have a default buying specification concerning sustainable fish, in which they can trust. Following this vision regarding the implementation of the sustainable food system approach (capacities for change), it is critical to put in place, within a coherent policy framework, concerted actions of governmental and market-based providers and innovative groups of citizen-consumers [75]. These policy interventions include information-based instruments.

With sustainability labels, responsibility for sustainable fish is being transferred from governments, producers, and retailers to consumers. Instead of governments regulating the sales of sustainable fish or retailers implementing sustainable fish, only policies [76], governments, retailers, and NGOs provide information to consumers. Consumers are expected to be aware of their responsibility and act responsibly through their decision-making at the point of purchase [77]. The environmental responsibility ascribed to the individual consumer has become part of mainstream policy-making, and the use of labels is regarded as an essential policy tool in this connection. Therefore, for a sustainable fish strategy to be successful, consumers need to be aware of the impact of their fish consumption and willing to take responsibility for their fish choices.

Nowadays, the industry has developed several transnational certification and labelling schemes to foster sustainable fisheries and to inform consumers and key stakeholders of the value chain. Retailers have a vantage position in the food chain and play a powerful role both downstream, having a closer relation to consumers at the point of sale, and upstream at the purchase level in controlling the activities of producers. Retailers can also promote sustainable fish practices by ensuring that their products are sourced from sustainable fisheries and fish farms.

\section{Limitation}

With regard to the limitations of this study, we highlight that, due to the restricted number of studies analyzed, the results should be generalized with caution. In addition, future research should focus on more fish species and countries in order to gain a better understanding of the current trends. Moreover, while there is evidence of price premiums in the retail market for sustainability-labelled fish products, there are very few studies examining the existence of price premiums at the producer level.

Supplementary Materials: The following are available online at http://www.mdpi.com/2071-1050/12/23/10008/s1. Table S1. Overview of selected papers. 
Author Contributions: The work is a result of equal contribution and collaboration between the authors in each part of the paper. Conceptualization, G.M. and M.D.; methodology, G.M.; software, G.C.; validation, G.D.V. and G.P.; formal analysis, G.M. and G.C.; investigation, G.M. and G.D.V.; resources, G.M. and G.C.; data curation, G.M.; writing-original draft preparation, G.M. and G.P.; writing-review and editing, G.M. and G.C.; visualization, G.D.V.; supervision, M.D. and G.P.; project administration, M.D.; funding acquisition, G.C. All authors have read and agreed to the published version of the manuscript.

Funding: This research was funded by the project "Economic assessments of the sustainability of agri-food systems" by UNICT 2016-2018 "Piano per la Ricerca. Linea di intervento 2-Seconda annualità P7/WP2 (5A722192141)". Project leader: Gaetano Chinnici.

Conflicts of Interest: The authors declare no conflict of interest.

\section{References}

1. Uchida, H.; Onozaka, Y.; Morita, T.; Managi, S. Demand for ecolabeled seafood in the Japanese market: A conjoint analysis of the impact of information and interaction with other labels. Food Policy 2014, 44, 68-76. [CrossRef]

2. Cahu, C.; Salen, P.; De Lorgeril, M. Farmed and wild fish in theprevention of cardiovascular diseases: Assessing possible differences in lipid nutritional values. Nutr. Metab. Cardiovasc. Dis. 2004, 14, $34-41$. [CrossRef]

3. FAO. The State of World Fisheries and Aquaculture 2020. Sustainability in Action; FAO: Rome, Italy, 2020. [CrossRef]

4. Martin, S.M.; Cambridge, T.A.; Grieve, C.; Nimmo, F.M.; Agnew, D.J. An evaluation of environmental changes within fisheries involved in the marine stewardship council certification scheme. Rev. Fish. Sci. 2012, 20, 61-69. [CrossRef]

5. Cicia, G.; Colantuoni, F. Willingness to pay for traceable meat attributes: A meta-analysis. Int. J. Food Syst. Dyn. 2010, 1, 252-263.

6. Konefal, J. Environmental movements, market-based approaches, and neoliberalization: A case study of the sustainable seafood movement. Organ. Environ. 2013, 26, 336-352. [CrossRef]

7. Del Giudice, T.; Cavallo, C.; Caracciolo, F.; Cicia, G. What attributes of extra virgin olive oil are really important for consumers: A meta-analysis of consumers' stated preferences. Agric. Food Econ. 2015, 3, 1-15. [CrossRef]

8. Wagner, B.A.; Young, J.A. Seabass and seabream farmed in the mediterranean: Swimming against the tide of market orientation. Supply Chain Manag. Int. J. 2009, 14, 435-446. [CrossRef]

9. Read, P.; Fernandes, T. Management of environmental impacts of marine aquaculture in Europe. Aquaculture 2003, 226, 139-163. [CrossRef]

10. Olson, J.; Clay, P.M.; Da Silva, P.P. Putting the seafood in sustainable food systems. Mar. Policy 2014, 43, 104-111. [CrossRef]

11. Maroušek, J.; Maroušková, A.; Myšková, K.; Váchal, J.; Vochozka, M.; Žák, J. Techno-economic assessment of collagen casings waste management. Int. J. Environ. Sci. Technol. 2015, 12, 3385-3390. [CrossRef]

12. Maesano, G.; Carra, G.; Vindigni, G. Sustainable dimensions of seafood consumer purchasing behaviour: A review. Qual. Access Success 2019, 20, 358-364.

13. Brécard, D.; Hlaimi, B.; Lucas, S.; Perraudeau, Y.; Salladarré, F. Determinants of demand for green products: An application to eco-label demand for fish in Europe. Ecol. Econ. 2009, 69, 115-125. [CrossRef]

14. Lanfranchi, M.; Giannetto, C.; D’Amico, M.; Di Vita, G. Analysis of Demand determinants of fish products in Messina: An economic survey on the fish consumption. Qual. Access Success 2014, 15, 106-108.

15. Littell, J.H.; Corcoran, J.; Pillai, V. Systematic Reviews and Meta-Analysis; Oxford University Press: Oxford, UK, 2008.

16. Golbabaei, F.; Yigitcanlar, T.; Paz, A.; Bunker, J. Individual predictors of autonomous vehicle public acceptance and intention to use: A systematic review of the literature. J. Open Innov. Technol. Mark. Complex. 2020, 6, 106. [CrossRef]

17. González-Rubio, J.; Navarro-López, C.; López-Nájera, E.; López-Nájera, A.; Jiménez-Díaz, L.; Navarro-López, J.D.; Nájera, A. A systematic review and meta-analysis of hospitalised current smokers and COVID-19. Int. J. Environ. Res. Public Health 2020, 17, 7394. [CrossRef] 
18. Olesen, I.; Alfnes, F.; Røra, M.B.; Kolstad, K. Eliciting consumers' willingness to pay for organic and welfare-labelled salmon in a non-hypothetical choice experiment. Livest. Sci. 2010, 127, 218-226. [CrossRef]

19. Davidson, K.; Pan, M.; Hu, W.; Poerwanto, D. Consumers' willingness to pay for aquaculture fish products vs. wild-caught seafood-A case study in Hawaii. Aquac. Econ. Manag. 2012, 16, 136-154. [CrossRef]

20. Solgaard, H.; Yang, Y. Consumers' perception of farmed fish and willingness to pay for fish welfare. Br. Food J. 2011, 113, 997-1010. [CrossRef]

21. Grimsrud, K.M.; Nielsen, H.M.; Navrud, S.; Olesen, I. Households' willingness-to-pay for improved fish welfare in breeding programs for farmed Atlantic salmon. Aquaculture 2013, 372, 19-27. [CrossRef]

22. Zhou, G.; Hu, W.; Huang, W. Are consumers willing to pay more for sustainable products? A Study of eco-labeled tuna steak. Sustainability 2016, 8, 494. [CrossRef]

23. Zander, K.; Feucht, Y. Consumers' willingness to pay for sustainable seafood made in Europe. J. Int. Food Agribus. Mark. 2018, 30, 251-275. [CrossRef]

24. Johnston, R.J.; Wessells, C.R.; Donath, H.; Asche, F. Measuring consumer preferences for ecolabeled seafood: An international comparison. J. Agric. Resour. Econ. 2001, 20-39.

25. Johnston, R.J.; Roheim, C.A. A battle of taste and environmental convictions for ecolabeled seafood: A contingent ranking experiment. J. Agric. Resour. Econ. 2006, 283-300.

26. Whitmarsh, D.; Wattage, P. Public Attitude towards the environmental impact of salmon aquaculture in Scotland. Eur. Environ. 2006, 16, 108-121. [CrossRef]

27. Erwann, C. Eco-Labelling: A new deal for a more durable fishery management? Ocean Coast. Manag. 2009, 52, 250-257. [CrossRef]

28. Ariji, M. Conjoint analysis of consumer preference for bluefin tuna. Fish. Sci. 2010, 76, 1023-1028. [CrossRef]

29. Goyert, W.; Sagarin, R.; Annala, J. The promise and pitfalls of Marine Stewardship Council certification: Maine lobster as a case study. Mar. Policy 2010, 34, 1103-1109. [CrossRef]

30. Roheim, C.A.; Asche, F.; Santos, J.I. The elusive price premium for ecolabelled products: Evidence from seafood in the UK Market. J. Agric. Econ. 2011, 62, 655-668. [CrossRef]

31. Xu, P.; Zeng, Y.; Fong, Q.; Lone, T.; Liu, Y. Chinese consumers' willingness to pay for green-and eco-labeled seafood. Food Control 2012, 28, 74-82. [CrossRef]

32. Fernández-Polanco, J.; Loose, S.M.; Luna, L. Are retailers' preferences for seafood attributes predictive for consumer wants? Results from a choice experiment for seabream (sparus aurata). Aquac. Econ. Manag. 2013, 17, 103-122. [CrossRef]

33. Sogn-Grundvåg, G.; Larsen, T.A.; Young, J.A. The value of line-caught and other attributes: An exploration of price premiums for chilled fish in UK supermarkets. Mar. Policy 2013, 38, 41-44. [CrossRef]

34. Sogn-Grundvåg, G.; Larsen, T.A.; Young, J.A. Product differentiation with credence attributes and private labels: The case of whitefish in UK supermarkets. J. Agric. Econ. 2014, 65, 368-382. [CrossRef]

35. Uchida, H.; Roheim, C.A.; Wakamatsu, H.; Anderson, C.M. Do Japanese consumers care about sustainable fisheries? Evidence from an Auction of Ecolabelled Seafood. Aust. J. Agric. Resour. Econ. 2014, 58, 263-280. [CrossRef]

36. Asche, F.; Larsen, T.A.; Smith, M.D.; Sogn-Grundvåg, G.; Young, J.A. Pricing of ecolabels with retailer heterogeneity. Food Policy 2015, 53, 82-93. [CrossRef]

37. Blomquist, J.; Bartolino, V.; Waldo, S. Price premiums for providing eco-labelled seafood: Evidence from MSC-certified cod in Sweden. J. Agric. Econ. 2015, 66, 690-704. [CrossRef]

38. Fonner, R.; Sylvia, G. Willingness to Pay for Multiple Seafood Labels in a Niche Market. Mar. Resour. Econ. 2015, 30, 51-70. [CrossRef]

39. Lim, K.H.; Grebitus, C.; Hu, W.; Nayga, R.M., Jr. More than Meets the Eye: Consumers' Willingness to Pay for Marine Stewardship Council's Certified Seafood. In Proceedings of the 2015 AAEA \& WAEA Joint Annual Meeting, San Francisco, CA, USA, 26-28 July 2015. No. 330-2016-13795.

40. Bronnmann, J.; Asche, F. The Value Of Product Attributes, Brands And Private Labels: An Analysis Of Frozen Seafood In Germany. J. Agric. Econ. 2016, 67, 231-244. [CrossRef]

41. Chen, X.; Alfnes, F.; Rickertsen, K. Consumer preferences, ecolabels, and effects of negative environmental information. AgBioForum 2015, 18, 327-336.

42. Salladarré, F.; Brécard, D.; Lucas, S.; Ollivier, P. Are French Consumers Ready To Pay A Premium For Eco-Labeled Seafood Products? A Contingent Valuation Estimation with Heterogeneous Anchoring. Agric. Econ. 2016, 47, 247-258. [CrossRef] 
43. Rickertsen, K.; Alfnes, F.; Combris, P.; Enderli, G.; Issanchou, S.; Shogren, J.F. French Consumers' Attitudes And Preferences Toward Wild And Farmed Fish. Mar. Resour. Econ. 2017, 32, 59-81. [CrossRef]

44. Sun, C.H.J.; Chiang, F.S.; Owens, M.; Squires, D. Will American Consumers Pay More For Eco-Friendly Labeled Canned Tuna? Estimating Us Consumer Demand for Canned Tuna Varieties Using Scanner Data. Mar. Policy 2017, 79, 62-69.

45. Vitale, S.; Biondo, F.; Giosuè, C.; Bono, G.; Okpala, C.O.R.; Piazza, I.; Spovieri, M.; Pipitone, V. Consumers' Perception And Willingness To Pay For Eco-Labeled Seafood In Italian Hypermarkets. Sustainability 2020, 12, 1434. [CrossRef]

46. Defrancesco, E. The Beginning of Organic Fish Farming in Italy; University of Padova: Padua, Italy, 2003.

47. Disegna, M.; Mauracher, C.; Procidano, I.; Trevisan, G. Characteristics of Production and Consumption of Organic Trout in Italy. New Medit 2009, 8 (Suppl. 3), 17-26.

48. Stefani, G.; Scarpa, R.; Cavicchi, A. Exploring Consumer's Preferences for Farmed Sea Bream. Aquac. Int. 2012, 20, 673-691. [CrossRef]

49. Mauracher, C.; Tempesta, T.; Vecchiato, D. Consumer Preferences Regarding the Introduction of New Organic Products. The Case of the Mediterranean Sea Bass (Dicentrarchus Labrax) In Italy. Appetite 2013, 63, 84-91. [CrossRef] [PubMed]

50. Isaac, A.Y.; Nielsen, M.; Nielsen, R. Organic Salmon-Considered A Fisheries or Agricultural Product among Consumers? In 2015 EAFE (European Association of Fisheries Economists) Conference Papers (No. 003); Nisea: Via Irno, Salerno, Italy, 2015.

51. Ankamah-Yeboah, I.; Nielsen, M.; Nielsen, R. Price Premium of Organic Salmon in Danish Retail Sale. Ecol. Econ. 2016, 122, 54-60. [CrossRef]

52. Claret, A.; Guerrero, L.; Aguirre, E.; Rincón, L.; Hernández, M.D.; Martínez, I.; Peleteiro, J.B.; Grau, A.; Rodríguez-Rodríguez, C. Consumer Preferences for Sea Fish Using Conjoint Analysis: Exploratory Study of the Importance of Country of Origin, Obtaining Method, Storage Conditions and Purchasing Price. Food Qual. Prefer. 2012, 26, 259-266. [CrossRef]

53. Cosmina, M.; Demartini, E.; Gaviglio, A.; Mauracher, C.; Prestamburgo, S.; Trevisan, G. Italian consumers' attitudes towards small pelagic fish. New Medit 2012, 11, 52-57.

54. Jaffry, S.; Pickering, H.; Ghulam, Y.; Whitmarsh, D.; Wattage, P. Consumer choices for quality and sustainability labelled seafood products in the UK. Food Policy 2004, 29, 215-228. [CrossRef]

55. Alfnes, F.; Rickertsen, K. SC-X: Calibrating Stated Choice Surveys with Experimental Auction Markets; No. 376-2016-20478. In Proceedings of the American Agricultural Economics Association Annual Meeting, Montreal, QC, Canada, 27-30 July 2003.

56. Costanigro, M.; Mccluskey, J.J.; Goemans, C. The Economics of Nested Names: Name Specificity, Reputations, and Price Premia. Am. J. Agric. Econ. 2010, 92, 1339-1350. [CrossRef]

57. Verbeke, W.; Vermeir, I.; Brunsø, K. Consumer evaluation of fish quality as basis for fish market segmentation. Food Qual. Prefer. 2007, 18, 651-661. [CrossRef]

58. Te Velde, H.; Aarts, N.; Van Woerkum, C. Dealing With Ambivalence: Farmers' And Consumers' Perceptions Of Animal Welfare In Livestock Breeding. J. Agric. Environ. Ethics 2002, 15, 203-219. [CrossRef]

59. Parkes, G.; Swasey, J.H.; Underwood, F.M.; Fitzgerald, T.P.; Strauss, K.; Agnew, D.J. The effects of catch share management on MSC certification scores. Fish. Res. 2016, 182, 18-27. [CrossRef]

60. Roheim, C.A.; Sudhakaran, P.O.; Durham, C.A. Certification of shrimp and salmon for best aquaculture practices: Assessing consumer preferences in Rhode Island. Aquac. Econ. Manag. 2012, 16, 266-286. [CrossRef]

61. Tidwell, J.H.; Allan, G.L. Fish as Food: Aquaculture's Contribution. EMBO Rep. 2001, 2, 958-963. [CrossRef] [PubMed]

62. Asche, F.; Bjørndal, T.; Young, J.A. Market Interactions for Aquaculture Products. Aquac. Econ. Manag. 2001, 5, 303-318. [CrossRef]

63. O'dierno, L.J.; Govindasamy, R.; Puduri, V.S.; Myers, J.J.; Islam, S. Consumer Perceptions and Preferences for Organic Aquatic Products: Results from the Telephone Survey; No. 1326-2016-103615; Rutgers University, Department of Agricultural, Food and Resource Economics: New Brunswick, NJ, USA, 2006.

64. Brunsø, K.; Verbeke, W.; Olsen, S.O.; Jeppesen, L.F. Motives, barriers and quality evaluation in fish consumption situations. Br. Food J. 2009, 111, 669-716. [CrossRef] 
65. Birch, D.; Lawley, M.; Hamblin, D. Drivers and barriers to seafood consumption in Australia. J. Consum. Mark. 2012, 29, 64-73. [CrossRef]

66. Lawley, M.; Birch, D.; Hamblin, D. An Exploratory Study into the Role and Interplay of Intrinsic and Extrinsic Cues in Australian Consumers' Evaluations of Fish. Australas. Mark. J. 2012, 20, 260-267. [CrossRef]

67. Hinkes, C.; Schulze-Ehlers, B. Consumer attitudes and preferences towards pangasius and tilapia: The role of sustainability certification and the country of origin. Appetite 2018, 127, 171-181. [CrossRef]

68. Luomala, H.T. Exploring the role of food origin as a source of meanings for consumers and as a determinant of consumers' actual food choices. J. Bus. Res. 2007, 60, 122-129. [CrossRef]

69. Pérez-Ramírez, M.; Castrejón, M.; Gutiérrez, N.L.; Defeo, O. The Marine Stewardship Council Certification in Latin America and the Caribbean: A Review of Experiences, Potentials and Pitfalls. Fish. Res. 2016, 182, 50-58. [CrossRef]

70. Grunert, K.G.; Hieke, S.; Wills, J. Sustainability labels on food products: Consumer motivation, understanding and use. Food Policy 2014, 44, 177-189. [CrossRef]

71. Balabanis, G.; Diamantopoulos, A. Domestic country bias, country-of-origin effects, and consumer ethnocentrism: A multidimensional unfolding approach. J. Acad. Mark. Sci. 2004, 32, 80-95. [CrossRef]

72. Carrà, G.; Peri, I.; Vindigni, G.A. Diversification Strategies for sustaining small-scale fisheries activity: A multidimensional integrated approach. Riv. Di Studi Sulla Sostenibilità 2014, 1, 79-99.

73. Verbeke, W. Consumer Acceptance of Functional Foods: Socio-Demographic, Cognitive and Attitudinal Determinants. Food Qual. Prefer. 2005, 16, 45-57. [CrossRef]

74. Gutiérrez, A.T.; Morgan, S.K. The Influence of the Sustainable Seafood Movement in the US and UK Capture Fisheries Supply Chain and Fisheries Governance. Front. Mar. Sci. 2015, 2, 72. [CrossRef]

75. Middlemiss, L. Reframing individual responsibility for sustainable consumption: Lessons from environmental justice and ecological citizenship. Environ. Values 2010, 19, 147-167. [CrossRef]

76. Alfnes, F. Selling only sustainable seafood: Attitudes toward public regulation and retailer policies. Mar. Policy 2017, 78, 74-79. [CrossRef]

77. Thøgersen, J. How May Consumer Policy Empower Consumers for Sustainable Lifestyles? J. Consum. Policy 2005, 28, 143-177. [CrossRef]

Publisher's Note: MDPI stays neutral with regard to jurisdictional claims in published maps and institutional affiliations.

(C) 2020 by the authors. Licensee MDPI, Basel, Switzerland. This article is an open access article distributed under the terms and conditions of the Creative Commons Attribution (CC BY) license (http://creativecommons.org/licenses/by/4.0/). 